\title{
VIEWPOINT OF THE SUPREME COURT OF NEPAL ON THE ARBITRATION PROCESS IN THE LIGHT OF PARTY AUTONOMY
}

\author{
Sanad Devkota \\ Associate Professor, Nepal law campus Kathamandu, TU \\ Corresponding author: lawyersanad@gmail.com
}

\begin{abstract}
Arbitration is a contract-based form of binding dispute resolution. In other words, a party's right to refer a dispute to arbitration depends on the existence of an agreement between them and the other parties to the dispute that the dispute may be referred to arbitration.
\end{abstract}

Arbitration is a private process where disputing parties agree that one or several individuals can make a decision about the dispute after receiving evidence and hearing arguments. The arbitration process is similar to a trial in that the parties make opening statements and present evidence to the arbitrator.

Conflicts have existed in all cultures, religions and societies since time immemorial, as long as human have walked the earth. Human society is a repertoire where differences arise and persist as salient features, but this is also a platform where varieties of disputes find management in the form of resolution to energize the society. As conflicts are an integral part of human interaction, one must learn to deal with them tactfully, conventionally, disputes - commercial or otherwise were resolved by litigation but due to delays, costs, publicity and technicality associated with litigation, alternative dispute resolution (ADR) processes evolved. Various means of ADR or out of court settlement of disputes such as negotiation, conciliation and arbitration have come into practice.

In the modern era, the business activities are increasing day by day. Along with the business activities, its complexities, differences, and disputes are also increasing day by day. The traditional method of settling disputes is the litigation process in the court of law. From the perspective of concerned parties, settlement of these disputes as quick as possible is desired. But because of the lengthily procedure and case load settlement through court is not possible. For this reason, parties were 
looking for the alternative process where both the parties can trust impartial person who will solve their disputes within short period of time.

Keywords: arbitration - arbitral agreements - party autonomy - arbitral award Supreme Court of Nepal.

\section{INTRODUCTION}

Arbitration is a procedure in which a dispute is submitted, by agreement of the parties, to one or more arbitrators who make a binding decision on the dispute. In choosing arbitration, the parties opt for a private dispute resolution procedure instead of going to court. Arbitration is a form of alternative dispute resolution (ADR), used in place of litigation (going to court) in the hope of settling a dispute without the cost and time of a court cage Litigation which is a court-based process that involves a decision that is binding on both parties and a process of appealing the decision.

The differences between arbitration and litigation involve the processes themselves and the result of decisions on the disputes. Both are formal processes, but arbitration in many cases is less costly and results in shorter settlement times.

In the modern era, the business activities are increasing day by day. Along with the business activities, its complexities, differences, and disputes are also increasing day by day. The traditional method of settling disputes is the litigation process in the court of law. From the perspective of concerned parties, settlement of these disputes as quick as possible is desired. But because of the lengthily procedure and case load settlement through court is not possible. For this reason, parties were looking for the alternative process where both the parties can trust impartial person who will solve their disputes within short period of time. (Adhikari 2063 B.S.) Arbitration is the reference of a dispute or differences between not less than two parties for determination, after hearing both sides by persons other than a court of competent jurisdiction (Halsbury 2006).

It is a form of dispute settlement done outside the premises of any court where the dispute is referred to one or more impartial persons, in odd numbers, generally by the parties of dispute. The decision of such third impartial party appointed to resolve the dispute known as award is agreed upon by the parties as a binding one. An arbitral proceeding takes place keeping in mind amicable intra- party relationship and is more of a winwin way of dispute resolution rather than win- lose (Halsbury 2006). 
Arbitration is an effective and enforceable method of Alternative dispute resolution. It is the most common method of dispute resolution which arises from the agreement of the parties in dispute. Renowned jurist of International Law, Oppenheim says, "Peaceful resolution if dispute between persons is our universally recognized norm, as it is an ingredient of civilization" (Oppenheim 2001). Therefore, disputes as such are inevitable. One of the best possible means is to solve through pacific settlement of disputes.

Arbitration is a method of private resolution which arises from the agreement of parties in the dispute. Arbitration is a reference to the decision of one or more persons, either or without an empire, of some matter or matters in difference between the parties (David 1997). It is a process whereby parties voluntarily refer their disputes to an impartial third person, an arbitrator, selected by them, for a decision based on evidence and arguments to be presented before him (Robert 1997).

Various International Rules have been developed to facilitate the International Commercial Arbitration. Major ones of them are: New York Convention, 1958; European Convention 1961; UNICITRAL Arbitration Rules 1976; ICC Rules of Conciliation and Arbitration, 1998, etc. These standards, though related to institutional rules of international commercial arbitration, also recognize to some extent the involvement of domestic court. After the outcome of UNICITRAL Model Law on International Commercial Arbitration, 1985, a trend of minimizing the courts role in arbitration is encouraged and autonomy to the parties increased.

A basic principle in international commercial arbitration is that of party autonomy. It is described by the authors of Redfern and Hunter in the following terms: "Party autonomy is the guiding principle in determining the procedure to be followed in an international commercial arbitration. It is a principle that has been endorsed not only in national laws, but by international arbitral institutions and organizations. The legislative history of the Model Law shows that the principle was adopted without opposition..." (Redfern 2004).

Redfern and Hunter go on to cite Article 19(1) of the UNCITRAL Model Law (Model Law) which provides: "Subject to the provisions of this Law, the parties are free to agree on the procedure to be followed by the arbitral tribunal in conducting the proceedings" (Redfern 2004). 
Instead of placing procedural barriers in the way of parties proceeding to arbitration or allowing excessive intrusion by national laws and courts in the process, the principle of 'party autonomy' is now firmly established as the benchmark for international arbitration law worldwide. The principle of party autonomy has been accepted throughout the world. Related to this, it has been recognized by international conventions, for instance, according to UNCITRAL Model Law, The arbitral tribunal shall decide the dispute in accordance with such rules of law as are chosen by the parties as applicable to the substance of the dispute. This principle can be found in New York Convention as well. For example, according to this Convention, recognition and enforcement of the award can be refused if the composition of the arbitral authority or the arbitral procedure was not in accordance with the agreement of the parties. The Rules of International Chamber of Commerce (ICC) also includes some articles about party autonomy. As an illustration, the parties shall be free to agree upon the rules of law to be applied by the Arbitral Tribunal to the merits of the dispute.

\section{RESEARCH METHODOLOGY}

This research work is doctrinal one which is followed by descriptive and analytical methods. The data and information required for the study are collected through review of the available literatures, data, and research reports. Primary source as various legislations, international conventions which come in close connection with it has also been reviewed. Basically Precedent, established by Supreme Court of Nepal having close connection in this regard has been given due consideration. Secondary source of authority as required for the research has been collected from various Books, Research Reports, news reports and other relevant sources. Descriptive and analytical approach is used to analyze the data. Identification of dependent variables and other methodological parts are consulted properly.

\section{PROVISIONS ON PARTY AUTUNOMY IN THE ARBITRATION ACT, 1999 (2055 B.S.)}

Arbitration Act, 1999 (2055 B.S.) provides the process of timely dispute resolution through the decision of arbitrators selected by the disputing parties themselves. The arbitrator shall settle the disputes related to the issues under the agreement according to the procedures prescribed in that agreement, if any, and if not, according to this Act [Sec. 3(1)]. The arbitrators may settle the dispute on the basis of principle of justice and 
conscience or natural justice only when they are authorized to do so by the parties [Sec. 18(2)]. The parties to dispute are provided with facility of close and confidential hearing as arbitration proceedings are carried out in-camera (Sec.19). The arbitrators shall pronounce the decision ordinarily within One hundred and twenty days from the date of submission of documents (Sec.24). The concerned parties have obligation to implement the arbitral award within forty-five days of receive the copy of award (Sec.31). Foreign arbitral awards are also enforced in Nepal. This provision assures international investors for implementation of arbitral Award given in the jurisdiction of their home country as well. Party seeking such implementation has to submit an application to the Appellate Court with original or certified copy of arbitral Award and agreement (Sec.34).

The legal regime of the applicant's home country or that of country where the arbitral Award is rendered should not prevent the recognition and enforcement of any arbitral Award given in Nepal. Likewise, the foreign arbitral award is not enforced in Nepal if such award will be inconsistent with public policy pursuant to Section 34(4) of the Act.

\section{DECISIONS OF THE SUPREME COURT OF NEPAL RELEVANT TO PARTY AUTONOMY IN ARBITRATION}

Hari Shankar Tripathi, Governor, Nepal Rastra Bank (NRB) et.al. v. Rajendra Man Serchan, Managing Director, Vijay Construction Co. (Nepal Kanoon Patrika, 2052)

Facts: NRB and the Vijaya Construction Company entered into a contract of constructing a sub-branch building of the bank at Dhangadi in 2040/05/10. The construction work stops in 2041/04/07 after the completion of $34.66 \%$ of construction work because the bank didn't provide drawings and maps to the company and also the bank was unable to give directions for the construction to the company. The company then claimed for the loss of Rs. 1,48,11,036/01 from the bank and wrote an application to the Kathmandu District Court for the appointment of arbitrator. Bank claimed that they provided the company with necessary drawing and maps yet the company made excuses. The bank rather claimed for the loss of Rs. 15,98,777/56 from the construction company. The arbitrator resolved the dispute between the bank and the company which said the bank was liable to pay the loss of $17,01,808,10$ to the company. The bank wrote an application mentioning about the wrong decision of the arbitrator. Appellate Court, Patan rendered the judgment of the decision of the arbitrator being fair. NRB then moved 
to the Supreme Court with the fact that Appellate Court rendered the wrong judgment even after the bank mentioned that the arbitrator provided the decision against the terms and conditions of the agreement. Hari Shankar Tripathi, Governor, NRB et.al. challenged the decision of the Appellate Court Patan dated 2049/03/16 that upheld the award of the arbitrator given on 2047/03/24, which directed the NRB to pay out the sum of 1.7 million rupees to the contractor Vijaya Construction Co. The applicant filed the application of revision seeking to quash the judgment of Appellate Court arguing that court misinterpreted the Subsection (2)(f) of Section 21 of the Arbitration Act, 1981 (2038 B.S.) and did not properly examine whether the arbitrator has violated the terms of the contract while award was made.

Issue: Does the arbitral award relating to the claims and the legal consequences for damages within and in between the disputing parties is ought to have judicial test from Supreme Court? Is it possible to judge a counterclaim by the respondent during the arbitration which is initiated by the initiation of the claimant?

Ratio of the Decision: The Arbitrator appointed to arbitrate any dispute should provide both of the parties with equal opportunity to present their claims and rebuttals with relevant supporting evidences. Arbitration Act, 1981 (2038 B.S.) does not provide with any definite procedure on how the parties should present their claims and rebuttals. In such a context, law and principles on arbitration do not obstruct in determining the procedures to be applied by the arbitrator by means of mutual consent in between the parties. The questions on how and in what way the respondent should present the rebuttal and counter claim, whether or not the respondent could submit the separate claim are the procedural matters to be set by the arbitrator.

Where arbitration as a means of dispute settlement is set out by the terms of the contract, the ground of such agreement is founded upon the mutual trust and good faith in between the disputing parties. While a party seeks arbitration on the basis of prior agreement, denial of such proposal by other party is against the mutual understanding. It is itself clear by established principle of arbitration that without consent of the related parties, arbitrator cannot make decision on the matters beyond their preset scope during the appointment.

Analysis: Supreme Court's decision in this case is very much significant to establish the notion of party autonomy in the arbitration procedure. Strictly ruling out the possibility of intervention by the court in the matter that is 
once finalized by the arbitration, Supreme Court in its verdict, adheres to the international principle of fairness, transparency and finality of the arbitral award. Another important aspect found in this decision is the concept of party autonomy which should ensure the necessary procedural framework for the arbitrators to arbitrate the dispute. The whole procedures should be maintained on the basis of mutual consent, trust and good faith in between the disputing parties. Until and unless the parties consented upon the procedures, arbitrators are not free to decide upon the procedural matters on their discretion. Moreover, Supreme Court has taken high note on maintaining balance between the autonomy to be exercised by the parties and the autonomy of the arbitrator while providing the award on the disputed matter based on the given terms of reference. As the judiciary has emphasized on preserving the party autonomy in maintaining the procedural fairness during the arbitration, this case conveys good message to the private investors and contractors worldwide that no investor shall fall prey of the separate claims which could be furnished by the State authorities in Nepal, while arbitrating the disputes through arbitration.

Ramesh Bhomi v. Appellate Court, Patan (Supreme Court Bulletin, 2071)

Facts: According to the letter written by applicant Nepal Children Association to Brihaspati Bidhya Sadan Higher Secondary School on $2066 / 9 / 30$, the rent mentioned in the agreement made between them on $2059 / 05 / 11$ is not sufficient and they are willing to terminate the agreement and make new agreement as per the direction of Commission for Investigation of Abuse of Authority (CIAA). After the discussion between both parties regarding increment of rent, Bidhya Sadan denies it. Dispute arises between both parties regarding to the terms and conditions mentioned in the agreement. It is mentioned in the agreement that parties will use the method of arbitration if dispute arises between them before taking the issue in the court. Appellate court sends an order to the applicant to choose an arbitrator but the applicant directly goes to the Supreme court with a writ petition to quash the order.

Issue: "Notwithstanding otherwise contained in the agreement, the process of appointing arbitrators must be started within 30 days from the date when the reason for the settlement of a dispute through arbitration arises" whether this provision of Sec. 6 of the Act is mandatory or not. 
Ratio of the Decision: Supreme Court renders the justice which says the time limitation of appointing an arbitrator isn't mentioned in the agreement. Section 6(1) of the Arbitration Act provides the time limitation of three months for the initiation of settlement of dispute between the parties through arbitration. But the applicant didn't mention time limitation in the writ petition so the order of appellate court is sustained and the writ petition is quashed.

Analysis: Supreme Court in this case discouraged the disputing party to enter into its extra-ordinary writ jurisdiction, while the alternative way of seeking the remedy through predefined contract is still not exhausted. This is important for the arbitration proceedings because, once the parties consent through their agreement for the submission of their disputes to arbitration panel, they must follow the procedure of the arbitration in good faith. If the disputing parties are allowed to enter into the writ jurisdiction, there would be no meaning of the predefined methodology of dispute settlement through the arbitration. So the party which autonomously chooses arbitration as a means of the settlement of disputes must go through it to settle the dispute rather than seeking the remedy from writ jurisdiction.

National Construction Co. Nepal v. Appellate Court, Patan (Supreme Court of Nepal, 2065)

Fact: Arbitration is a powerful and effective means of resolving disputes. In 2038 BS, the first Arbitration Act 2038 BS came into force and the legal system of resolving special disputes through arbitrators was introduced. Appellate Courts regarding the role and powers of the appointing authority and the role and powers of the Appellate Courts in appointing the arbitrator and the award given by the arbitrator It doesn't seem clear yet. With regard to these questions and the demands of the petition submitted, a decision has to be taken on the following:

A) What is the authority of the Appellate court regarding the appointment of arbitrator?

B) Can one party to the agreement reject the proposal made by the other party for the appointment of an arbitrator?

C) Shouldn't the Appellate court's decision to appoint Senior Advocate Laxmi Bahadur Nirala as a sole arbitrator on 2063.4.28 be overturned?

Issue: Whether the agreement to arbitrate would be terminated or not if one of the disputing party terminate the contract by showing any other reason, 
Whether the arbitration clause of the contract will be active for the purpose of dispute settlement or not.

Ratio of the Decision: Whenever the procedure for the appointment of the arbitrators as stipulated in the agreement is followed but still the arbitrators are not being appointed as per the specified numbers in the agreement, in such a situation, Appellate Court, as an appointing authority can appoint the arbitrators according to the Section 7 of the Arbitration Act, 1999 (2055 B.S.).Once the parties agree to settle the dispute through arbitration, both of the parties are unable to act directly or indirectly in such a manner to hinder the institution of the arbitration panel or to restrict in lodging the dispute before the arbitration panel. Once the parties agree to arbitrate any future disputes, none of the party can deny the proposal of the counterparty to appoint the arbitrator for the purpose of settlement of disputes. The contract entered into in the good faith cannot be altered unilaterally. The unilateral modification of the contract amounts to be against the international principle of stabilization clauses and principle of 'pacta sunt servanda' must be honored. Provided that one of the party might terminate the contract by showing any other reason, the agreement to arbitrate would not be terminated by the termination of contract. The arbitration clause of the contract would be active for the purpose of dispute settlement.

Analysis: Supreme Court in this case upholds the party autonomy in the arbitration but also promotes the role of court intervention where necessary to ensure arbitration procedure will be conducted in the smooth manner. Firstly, the arbitration procedure should always be conducted on the basis of mutual consent and the predefined agreement. Parties are free to choose the arbitration procedure, but if such procedures set in the agreement does not bring the arbitration in fruition, court should also use its authority to appoint the arbitrator. The international principle of 'pacta sunt servanda' is highlighted by the apex court in this case which is very much important for party autonomy and to handle the process in good faith. Though the contract is forcefully terminated by any party, the procedures of the arbitration would still be surviving, which is also very much important for the party autonomy.

Bikram Pandey v. Ministry of Physical Planning and Construction et.al. (Supreme Court of Nepal, 2067, No. 8)

Fact: If the parties do not co-operate each other in the matter of appointment of arbitrator and if there is no any provision in the agreement between the 
parties as to which body has the authority to appoint the arbitrator. It seems that the main dispute of this writ petition is over who should have the power to appoint the arbitrator.

Issue: Whether the provisions in the 'UNCITRAL Rule' are binding or not to the disputing parties, if it is not mentioned in the agreement.

Ratio of the Decision: The provisions in the UNCITRAL Rule are not automatically applicable as the national law in the course of settlement of any disputes through arbitration. Its usage and compulsiveness is based on the agreement between the parties and UNCITRAL Rule can be invoked by the parties who have entered into prior contract to follow such rule. The parties may also restrict in their agreement to which extent and what sort of the provisions of UNCITRAL Rule are binding during the arbitral proceedings in between them in the future disputes.

Whenever the party refuses to make use of the right to nominate and appoint the arbitrator from his/her side after the counterparty request for such, it is deemed the abandonment of the right to appoint the arbitrator. In such a case, UNCITRAL Rule has not compelled the party to appoint the arbitrator only through the permanent institution as defined in the Rule. For the purpose of appointment of the third umpire by the arbitrators appointed from the disputing parties from both side, the Appellate Court cannot appoint the arbitrators from both of the sides of the disputing parties. Such an act would be unlawful and extra-jurisdictional.

Analysis: Supreme Court has recognized the party autonomy in the applicability of UNCITRAL Rule in the course of dispute settlement through arbitration. Parties are free to mention in their contract whether or not to apply the UNCITRAL Rule in the arbitration process. Unless any party discard its right to appoint the arbitrator, the other authorities cannot appoint the arbitrator, and the apex court has ensured the party autonomy in this regard as well.

\section{CONCLUSIONS}

In the arbitration regime, party autonomy has gained much recognition. When drafting an arbitration agreement, parties are free to choose ad hoc or institutional arbitration, governing law, seat and venue of arbitration, number of arbitrators (odd number), their qualifications and other matters relevant to the procedure to be followed. The ability of parties 
to determine the procedure to be followed in appointing an arbitrator is a key manifestation of party autonomy.

Supreme Court's decision is much efficient to define the role and powers of parties in the arbitral proceedings. Supreme Court has provided important judicial interpretation on the legality of the court's interventions and its approach to limit such intervention in the process of arbitration is much more important of securing party's autonomy. Thus the Judicial trend in Nepal regarding the autonomy of the party in arbitration can be regarded as quite supportive. Supreme Court in its major decisions relevant to the arbitration has much focused on supporting and upholding the values of party autonomy in the dispute settlement through arbitration.

\section{REFERENCES}

Abdulhay, S. (2004). Corruption in international trade and commercial arbitration. London: Kluwer Law International.

Adhikari, A. \& Gautam, S. (2063 B.S.). Business law in Nepal (1 $1^{\text {st }}$ edn.). Kathmandu: Dhaulagiri Books. P.215.

Ansari, J. (2014). Party autonomy in arbitration: A critical analysis, 6(6) Researcher, 47: 53, http://www.sciencepub.net/ researcher, Accessed: 12.05.2019.

Bernstien, R. (1987). Hand book of arbitration practice. London: Sweet \& Maxwell Limited.

Bhandari, D.R. (2016). Business law. Kathmandu: ABC Books Publishers and Distributers House Pvt. Ltd.

Chukwumerije, Okezie (1994). A choice of law in international commercial arbitration. Quorum Books. p. 161.

David St. John Sutton et al. (1997). Russel on arbitration (21 $1^{\text {st }}$ edn.). London: Sweet \& Maxwell. p. 3.

Halsbury's Laws of England (2006). Lord Hailsham of St. Marylebone (4th edn.). UK: Lexis Nexis Butterworths. p.225.

Halsbury's Law of England (2006). Lord Hailsham of st. Marylebone (4 ${ }^{\text {th }}$ edn.). UK: Lexis Nexis Butterworths. P. 3.

Lawson, R. (1997). Business law. UK: Butterworth-Heinemann.

LBMC. (BS 2038), Arbitration Act, 1981. Law Book Management Committee, Babarmahal, Kathmandu. 
LBMC. (BS 2055), Arbitration Act, 1999, Law Book Management Committee, Babarmahal, Kathmandu.

Mackie, Karl et.al. (1995). Commercial Dispute Resolution. London: Butterworths.

Supreme Court of Nepal. (BS 2052). Nepal Kanoon Patrika 2052 No. 11, D.N.6110, Hari Shankar Tripathi, Governor, Nepal Rastra Bank (NRB) et.al v. Rajendra Man Serchan, Managing Director, Vijay Construction Co.

Supreme Court of Nepal. (BS 2065). Nepal Kanoon Patrika 2065, No.2, D.N.7933, National Construction Co. Nepal v. Appellate Court, Patan

Supreme Court of Nepal. (BS 2067). Nepal Kanoon Patrika 2067 No. 8, D.N. 8437, Bikram Pandey v. Ministry of Physical Planning and Construction et.al.

Oppenheim,L. (1952). International Law. Vol.2. London. p.3, cited from Bharat Bahadur Karki (2001). "Practice of Conciliation in the Settlement of Commercial Disputes in Nepal". Annual Survey of Nepalese Law. Kathmandu: Nepal Bar Council. p. 1.

Redfern and Hunter \& Blackaby and Partasides (2004). Law and Practice of International Commercial Arbitration (4th edn.). London: Sweet \& Maxwell. p. 315.

Sharma, I.C (2007). Principles and Practice of Arbitration in Construction in Nepal ( $2^{\text {nd }}$ edn.). (Kathmandu: Pairavi Prakashan. p. 118.

Sharma, I.C (2007). Principles and Practice of Arbitration in Construction in Nepal ( $2^{\text {nd }}$ edn.). (Kathmandu: Pairavi Prakashan. p. 118.

Supreme Court, Division Bench. (BS 2071). Supreme Court Bulletin. Decision Date: BS 2071/05/18, Ramesh Bhomi v. Appellate Court, Patan. 23(22): Series 544, p. 27

Treaty of Amity,Commerce and Navigation between Britain and America, 1794.

United Nations Commission on International Trade Model Law, 1985, revised 2006. 